\title{
PERBEDAAN ANTARA INTERVENSI SCAPULAR MOBILIZATION DAN MUSCLE ENERGY TECHNIQUE DALAM MENURUNKAN DISABILITAS BAHU PADA KONDISI FROZEN SHOULDER
}

\author{
Iit Selviani $^{1}$, Bagus Komang Satriyasa ${ }^{2}$, Sugijanto $^{3}$, Luh Made Indah Sri Handari Adiputra ${ }^{4}$, \\ Ni Nyoman Ayu Dewi ${ }^{5}$, I Dewa Ayu Inten Dwi Primayanti ${ }^{4}$ \\ ${ }^{1}$ Program Studi Magister Fisiologi Keolahragaan Universitas Udayana, Denpasar \\ ${ }^{2}$ Departement Farmakologi Fakultas Kedokteran Universitas Udayana, Denpasar \\ ${ }^{3}$ Fakultas Fisioterapi Universitas Esa Unggul, Jakarta \\ ${ }^{4}$ Departement Ilmu Faal, Fakultas Kedokteran Universitas Udayana, Denpasar \\ ${ }^{5}$ Departement Biokimia, Fakultas Kedokteran Universitas Udayana, Denpasar \\ E-Mail: iit.selviani@gmail.com
}

\begin{abstract}
ABSTRAK
Pendahuluan: Frozen shoulder adalah suatu kondisi idiopatik pada bahu yang ditandai dengan timbulnya nyeri dan keterbatasan pada sendi bahu. Frozen shoulder terjadi $2 \%$ hingga $5 \%$ populasi dan $40 \%$ pada penderita diabetes melitus. Frozen shoulder lebih banyak terjadi pada wanita dibanding pria dan terjadi pada rentang usia 40 hingga 65 tahun. Permasalahan yang muncul akibat terjadinya frozen shoulder dapat diberikan intervensi scapular mobilization dan muscle energy technique. Tujuan Penelitian ini untuk mengetahui perbedaan pemberian scapular mobilization dan muscle energi technique dalam menurunkan disabilitas bahu pada kondisi frozen shoulder.

Metode: Penelitian ini adalah penelitian eksperimental dengan rancangan pre dan post test group design. Sampel penelitian ini adalah pasien dengan kondisi frozen shoulder, berjumlah 18 sampel yang dipilih berdasarkan kriteria inklusi dan membagi menjadi dua kelompok. Kelompok I diberikan intervensi scapular mobilization sedangkan Kelompok II diberikan intervensi muscle energy technique selama 4 minggu. Pengukuran penurunan disabilitas bahu menggunakan Shoulder Pain and Disability Indeks (SPADI) dianalisis dengan independent t-test, untuk mencari rerata skor SPADI setelah perlakuan

Hasil: Pada uji beda penurunan disabilitas bahu sesudah intervensi kelompok I dengan kelompok II yang menggunakan independent sample t-test didapatkan penurunan disabilitas bahu dan hasil ini berbeda secara signifikan $p$ 0,006 ( $p<0,05)$, yang berarti ada perbedaan scapular mobilization dan muscle energy technique dalam menurunkan disabilitas bahu pada kondisi frozen shoulder. Simpulan: Intervensi scapular mobilization lebih baik dari muscle energy technique dalam menurunkan disabilitas bahu pada kondisi frozen shoulder.
\end{abstract}

Kata Kunci: Frozen Shoulder, Scapular Mobilization, Muscle Energy Technique, SPADI

\section{THE DIFFERENCE BETWEEN INTERVENTION OF SCAPULAR MOBILIZATION AND MUSCLE ENERGY TECHNIQUE TO REDUCE DISABILITY OF SHOULDER ON FROZEN SHOULDER CONDITIONS}

\footnotetext{
ABSTRACT

Introduction: Frozen shoulder is an idiopathic condition on shoulder which characterized by pain and limitation movement of shoulder joint. Frozen shoulder occurs $2 \%$ to $5 \%$ of population and $40 \%$ of in people with diabetes mellitus. Frozen shoulder sufferers are more common in women
} 
than man and occurs in the age range 40 to 65 years old. The impairments caused by frozen shoulder can be solved by scapular mobilization and muscle energy technique. The aim of this study to find out the difference between scapular mobilization and muscle energy technique to reduce disability of shoulder in frozen shoulder conditions.

Method: This is an experimental study with pre and post group design. This subject of this study is a patient with frozen shoulder, with total of 18 sample selected based on inclusive criteria and divided them into two groups. Group I was given Scapular mobilization and Group II was given Muscle Energy Technique for 4 weeks. Disability of shoulder were measured by SPADI and analyzed by Independent t-test to find out the mean of SPADI after given the intervention.

Results: In the different test of shoulder disability reduction after group I intervention with group II using independent sample t-test, there was a decrease in shoulder disability and this result was significantly different $p 0.006(p<0.05)$, which means that there were differences in scapular mobilization and muscle energy technique for reducing shoulder disability in frozen shoulder conditions. Conclusions: Scapular mobilization interventions are better than muscle energy technique in reducing shoulder disability in frozen shoulder conditions.

Keywords: Frozen Shoulder, Scapular Mobilization, Muscle Energy Technique, SPADI

\section{PENDAHULUAN}

Sendi bahu (shoulder joint) merupakan salah satu anggota gerak yang memiliki mobilitas yang tinggi dan mudah mengalami cedera, sehingga sering muncul gejala nyeri pada bahu (rotator cuff disease, impingement syndrome, frozen shoulder, disabilitas) yang dapat menyebabkan keterbatasan gerak hingga gangguan fungsi. ${ }^{1}$

keluhan yang terjadi pada bahu juga sering menyertai dalam aktivitas gerak tubuh manusia akibat kesenjangan dari fungsi tubuh ketika bergerak salah satunya Frozen Shoulder. Kondisi Frozen Shoulder ini merupakan kondisi idiopatik pada bahu yang ditandai dengan timbulnya nyeri dan keterbatasan pada sendi bahu. ${ }^{2}$

Frozen Shoulder atau capsulitis adhesive terjadi pada $2 \%$ hingga $5 \%$ populasi, dan biasanya terjadi $40 \%$ pada penderita diabetes melitus. Frozen Shoulder ini lebih banyak terjadi pada wanita dibanding pria, dan terjadi pada rentang usia 40 hingga 65 tahun. $^{3}$

Frozen Shoulder terdiri dari 3 fase yaitu: the freezing (painful phase) akan berakhir dalam 2-9 bulan. The frozen (stiff phase) akan berakhir dalam 4-12 bulan, dan the thawing (recovery phase) akan berakhir dalam 5-24 bulan. ${ }^{4}$

Pada penderita Frozen Shoulder biasanya akan mengalami kekakuan sendi bahu yang terasa nyeri pada malam hari dan hampir mengalami keterbatasan gerak yang berat pada gerakan eksternal sendi bahu secara aktif.

Scapular Mobilization adalah suatu teknik intervensi yang digunakan untuk manajemen gangguan muskuloskeletal bahu. Penerapan secara manual dengan mobilisasi keempat arah scapula glide yang dikontrol oleh terapis ke sendi scapulothoracic. Scapular mobilization ini bertujuan untuk memobilisasi sendi atau distraksi, sehingga memberikan jarak scapulothoracic dan otot akan terulur. Dengan mengontrol gerakan dari posisi scapula yang dapat membantu glenoid dalam posisi normal. ${ }^{5}$

Muscle Energy Technique adalah salah satu teknik metode manipulasi jaringan lunak yang diberikan kepada pasien dan bekerja sama dalam arahan yang diarahkan dan dikendalikan secara presisi dengan post kontraksi isometrik ${ }^{6}$ yang bertujuan untuk pengurangan tonus otot agonis dan meningkatkan fungsi muskuloskeletal dan dapat mengurangi nyeri.

Berdasarkan pemaparan tersebut, disimpulkan bahwa intervensi Scapular Mobilization memobilisasi gerakan pada skapula, sedangkan Muscle Energy Technique akan dapat memberikan efek 
relaksasi pada otot dengan post isometrik relaksasi tanpa menimbulkan nyeri dan kerusakan jaringan melalui tekanan minimal dan lembut sehingga tidak menimbulkan iritasi dengan tegangan yang kuat pada jaringan. $^{7}$

Sehingga diharapkan dari penelitian untuk mengetahui penurunan disabilitas bahu pada kondisi frozen shoulder.

\section{METODE PENELITIAN}

Rancangan penelitian adalah eksperimental dengan Kelompok I diberikan intervensi Scapular Mobilization, sedangkan Kelompok II diberikan intervensi Muscle Energy Technique. Pengukuran penurunan disabilitas bahu menggunakan Shoulder Pain and Disability Index (SPADI). ${ }^{8}$

Penelitian ini dilakukan di RSUD Arifin Achmad Pekanbaru, Poli Fisioterapi, pada Bulan Februari - April 2019. Penelitian dilakukan dengan frekuensi 3 kali seminggu yang berlangsung selama 4 minggu.

Pengontrolan dari kondisi Frozen shoulder ini berdasarkan jenis kelamin dan usia (tahun) berdasarkan kriteria inklusi yang terdapat pada frozen shoulder yaitu pasien dengan usia 40-65 tahun, pasien dengan adanya nyeri dan keterbatasan gerak, frozen shoulder fase II dan pasien yang mengalami disabilitas bahu . Sampel berjumlah 9 orang di masing-masing kelompok, yang diseleksi dari populasi Frozen Shoulder di Poli Fisioterapi RSUD Arifin Achmad Pekanbaru.

\section{HASIL PENELITIAN}

\section{Karakteristik Subjek Penelitian}

Tabel 1 menunjukkan bahwa pada karakteristik jenis kelamin dan usia (tahun) menunjukkan bahwa untuk seluruh karakteristik sampel antara kedua kelompok memiliki karakteristik yang hampir sama.

Tabel 1

Karakteristik Subjek Kelompok II

$\mathrm{n}(\%) \quad \mathrm{n}(\%)$

\begin{tabular}{ccc}
\hline $\begin{array}{c}\text { Jenis Kelamin } \\
\text { Laki-laki }\end{array}$ & $2(33,3)$ & $2(22,2)$ \\
Perempuan & $6(66,7)$ & $7(77,8)$ \\
\hline Usia (Tahun) & & \\
$41-45$ & $2(22,2)$ & $0(0)$ \\
$46-50$ & $1(11,2)$ & $2(22,2)$ \\
$51-55$ & $2(22,2)$ & $2(22,2)$ \\
$56-60$ & $2(22,2)$ & $4(44,4)$ \\
$61-65$ & $2(22,2)$ & $1(11,2)$ \\
\hline
\end{tabular}

\section{Uji Normalitas dan Homogenitas}

Tabel 2, keseluruhan data memiliki nilai $p$ $>0,05$ dan menunjukkan seluruh data pada masing-masing kelompok memiliki data berdistribusi normal. Sehingga uji hipotesis yang digunakan adalah parametrik. Uji homogenitas didapatkan nilai $p 0,346$ ( $p$ > $0,05)$ yang menunjukkan data homogen pada sebelum dan sesudah latihan.

Tabel 2

Uji Normalitas dan Uji Homogenitas Kelompok I Kelompok II (Shapiro-Wilk Test) p-value (Levene's Test)

\begin{tabular}{lccc} 
& $p$-value & $p$-value & \\
\hline Sebelum & 0,733 & 0,872 & 0,346 \\
Sesudah & 0,621 & 0,896 & \\
\hline
\end{tabular}

\section{Uji Beda rerata Shoulder Pain and Disability Index (SPADI) Pada Dua Kelompok}

Tabel 3 diperoleh nilai $p 0,0001(p<0,05)$ pada Kelompok I yang menunjukkan adanya penurunan disabilitas bahu setelah pemberian intervensi Scapular Mobilization. Pada Kelompok II nilai $p 0,0001(p<0,05)$ yang menunjukkan adanya penurunan disabilitas bahu setelah pemberian intervensi Muscle Energy Technique.

Tabel 3.

Hasil Uji beda SPADI pada kedua kelompok

\begin{tabular}{cccc}
\hline Kelompok & Sebelum & Sesudah & $\begin{array}{c}p- \\
\text { value }\end{array}$ \\
\hline I & $80,89 \pm 4,372$ & $74,00 \pm 4,555$ & 0,000 \\
II & $70,33 \pm 6,423$ & $6,44 \pm 6,635$ & 0,000 \\
\hline
\end{tabular}

\section{Uji Beda Skor SPADI sesudah}




\section{intervensi pada kelompok I dan kelompok II}

Berdasarkan analisis data yang didapat berdasarkan nilai statistik, menunjukkan bahwa pada data sesudah intervensi nilai $p$ $0,006(p<0,05)$. Hal ini menunjukkan adanya perbedaan yang signifikan pada kelompok I dan kelompok II. Nilai rerata skor SPADI sesudah intervensi pada kelompok I yaitu $74,00 \% \pm 4,555$. Sedangkan pada kelompok II didapatkan nilai sesudah intervensi $65,00 \% \pm 6635$. berdasarkan hasil tersebut, rerata skor SPADI sesudah intervensi pada kelompok I lebih besar dari rerata skor SPADI Kelompok II, dapat disimpulkan bahwa intervensi pada kelompok I mengalami penurunan disabilitas bahu yang lebih baik.

\section{PEMBAHASAN}

\section{Intervensi Scapular Mobilization dapat menurunkan disabilitas bahu pada kondisi frozen shoulder}

Berdasarkan kajian teori menjelaskan bahwa Scapular Mobilization ditujukan untuk memobilisasi sendi atau distraksi sehingga memberikan jarak scapulothoracal dan otot akan terulur. Dengan mengontrol gerakan dari posisi scapula yang dapat membantu glenoid dalam posisi normal. Sehingga gerakan akan lebih mobile dan meningkatkan fungsional pada bahu seperti mengangkat barang, melempar, menempatkan objek dari posisi rendah ke posisi lebih tinggi serta kegiatan menggosok punggung.

Scapular Mobilization memberikan efek sedative sehingga menurunkan ketegangan otot dan adanya peningkatan mobilitas sendi. ${ }^{9}$

Tujuan dari scapular mobilization ini yaitu dapat melepaskan perlengketan jaringan dan merelaksasikan otot-otot di sekitar shoulder sehingga dapat memperbaiki gerakan pada shoulder. Efek sedative yang ditimbulkan maka akan terjadi peningkatan sirkulasi sehingga metabolisme meningkat, iritasi berkurang dan dapat menyebabkan nyeri berkurang serta peningkatan lingkup gerak sendi. ${ }^{10}$

\section{Intervensi Muscle Energy Technique dapat} menurunkan disabilitas bahu pada kondisi frozen shoulder

Muscle energy technique merupakan suatu teknik manipulasi pada jaringan lunak yang menggabungkan dua metode yang diarahkan dan dikendalikan oleh pasien sesuai dengan instruksi dari fisioterapi dengan tepat yang dimulai dengan kontraksi isometrik yang berfungsi untuk memperbaiki kondisi muskuloskeletal dan mengurangi rasa tidak nyaman.

Efek Muscle Energy Technique untuk peningkatan lingkup gerak sendi melalui mekanisme fisiologis di balik perubahan ekstensibilitas otot - relaksasi refleks.

Muscle Energy Technique efektif dalam meningkatkan kemampuan fungsional bahu pada kondisi frozen shoulder. ${ }^{11}$

Muscle Energy Technique yang terjadi akibat refleks relaksasi otot dan tekstur jaringan yang dilakukan pada saat latihan ketika otot dalam keadaan relaksasi sehingga dapat mengurangi nyeri dan peningkatan fungsional. ${ }^{12}$

Intervensi Scapular Mobilization lebih baik dari Muscle Energy Technique dalam menurunkan disabilitas bahu pada kondisi frozen shoulder

Scapular mobilization pada sendi scapulothoracalis dan berlawanan arah dengan gerakan abduksi sendi glenohumeral merupakan intervensi peregangan jaringan lunak dan untuk kontraktur yang kronis pada region scapula dan region sendi glenohumeralis. Peregangan yang dilakukan dengan intensitas rendah, lebih nyaman, aman dan pasien lebih relaksasi dibandingkan dengan pemberian intervensi tinggi. Peregangan dengan intensitas rendah yang diberikan pada pelaksanaan terapi dengan waktu yang konsisten dapat meningkatkan ekstensibilitas jaringan kontraktil dan non kontraktil pada region scapula dan region glenohumeral sehingga dapat memperbaiki 
reverse scapulohumeral rhythm. ${ }^{13}$

Intervensi scapular mobilization menyebabkan terjadinya relaksasi terhadap otot-otot antagonis dan stabilitas pada otot agonis yang di latih, ketika pemberian dilakukan berulang dengan atau tanpa elastic rubber secara kontraksi konsentrik maupun eksentrik, latihan ini merangsang kontraksi otot secara ritmik sehingga terbentuk stabilitas dinamik pada otot-otot yang dilatih. Peregangan yang terjadi akan merangsang golgi tendon organ (GTO) sehingga terjadi refleks relaksasi, kontraksi dan peregangan intermitten akan memperbaiki mikrosirkulasi kapiler dan cairan sendi oleh pumping action sehingga mengurangi iritasi pada saraf aferen yang menimbulkan refleks keseimbangan tonus otot.

Keseimbangan tonus otot ini maka akan memberi koreksi terhadap posisi scapular ketika diam maupun ketika bergerak diamis, sehingga terbentuk gerakan scapular humeral rhythm yang proporsional dan menghindari gerakan yang dapat menimbulkan cedera berulang Perbaikan posisi dan gerak normal scapular terhadap scapulathoracic maka akan berpengaruh terhadap gerak normal dari scapulohumeral rhythm. Scapular Mobilization diberikan 2 set dari 10 pengulangan dengan waktu istirahat 30 detik di antara 4 set dalam seminggu selama 4 minggu. $^{14}$

Effect Muscle Energy Technique. Muscle energy technique merupakan teknik relaksasi otot dengan cara pemberian kontraksi isometrik sebelum dilakukan stretching yang bertujuan sebagai proprioceptive neuromuscular facilitation untuk penguatan atau meningkatkan tonus otot yang lemah, melepaskan hipertonus, stretching ketegangan otot dan fascia, meningkatkan fungsi muskuloskeletal, mobilisasi sendi pada keterbatasan gerak sendi, dan meningkatkan sirkulasi lokal, dan mengurangi nyeri. ${ }^{15}$

Pengaplikasian muscle energy technique menerapkan 2 konsep, yaitu post isometric relaxation (PIR) yang melibatkan golgi tendon dan reciprocal inhibition yang melibatkan muscle spindle (RI). ${ }^{7}$

Muscle energy technique menggunakan tahanan minimal sehingga tidak menimbulkan iritasi karena efeknya yang merelaksasi pada otot tanpa menimbulkan nyeri dan kerusakan jaringan melalui tekanan minimal dan lembut. $^{7}$

Proses mekanisme post isometric relaxation (PIR) melibatkan respons golgi tendon organ yang akan merangsang impuls saraf aferen memasuki akar dorsal di tulang belakang dan bertemu dengan inhibitory motor neuron. Hal ini berhenti di debit neuron aferen motorik impuls yang akan mencegah kontraksi yang terus menerus untuk relaksasi otot agonis. Sedangkan untuk proses mekanisme muscle spindle (RI) terjadi akibat receptor stretch terhadap serat otot spindle. Spindle otot memainkan pada proprioceptor untuk menanggapi peregangan sehingga memberikan feedback terhadap perubahan kontraksi, otot spindle di debit impuls saraf yang akan merangsang serat saraf eferen memasuki akar dorsal di tulang belakang bertemu dengan excitatory dan berhenti di neuron otot agonis yang akan menghambat neuron motor antagonis sehingga mencegah terjadinya kontraktur. Berdasarkan muscle pump theory, adanya kontraksi otot akan membantu meningkatkan perfusi di dalam jaringan otot ketika otot berkontraksi, vena di dalam otot tersebut akan mengalami kompresi dan akan mendorong darah menuju ke jantung. Pada saat relaksasi, tekanan serabut otot pada dinding vena akan menurun yang akan membuka lumen vena dan akan membuat tekanan menjadi rendah. Hal ini akan menyebabkan peningkatan tekanan gradien pada arteriovena yang akan mengakibatkan peningkatan aliran darah ke otot tersebut. Hal tersebut akan menyebabkan berkurangnya konsentrasi cytokine dan mengurangi sensitasi nosiseptor perifer. Adanya stretching memanfaatkan inhibisi dari terstimulasinya golgi tendon organ (GTO) dan Sel Pacini terhadap penurunan nyeri, inhibisi dari terstimulasinya golgi tendon organ (GTO) Memberikan efek peredaman pada motor neuron, sehingga timbul relaksasi pada muskulotendinous.

Intervensi Muscle energy Technique diberikan Pengulangan yang dilakukan 
sebanyak 5 kali per set, 1 sesi setiap hari, 3 hari dalam seminggu selama 4 minggu dengan setiap repetisi dipertahankan selama $7-10$ s. ${ }^{15}$

Sehingga pada penelitian ini menunjukkan bahwa ada perbedaan antara intervensi Scapular mobilization dan intervensi muscle energy technique dalam menurunkan disabilitas bahu pada kondisi frozen shoulder. Intervensi scapular mobilization lebih baik dari intervensi muscle energy technique dalam menurunkan disabilitas bahu pada kondisi frozen shoulder.

\section{KETERBATASAN PENELITIAN}

1. Sampel yang memiliki aktivitas beragam sebagai faktor risiko, sehingga mempengaruhi intervensi dan hasil penelitian serta peneliti tidak dapat mengawasi sampel yang masih terbiasa melakukan kebiasaan atau pekerjaan berat yang melibatkan bahu yang mana kebiasaan tersebut menghambat proses penyembuhan.

2. Jenis pekerjaan pada sampel tidak dikontrol dalam penelitian ini, sehingga mempengaruhi hasil dari intervensi.

\section{SIMPULAN}

1. Scapular Mobilization dapat menurunkan disabilitas bahu pada kondisi frozen shoulder

2. Muscle Energy Technique dapat menurunkan disabilitas bahu pada kondisi frozen shoulder

3. Intervensi Scapular Mobilization lebih baik dari Muscle energy technique dalam menurunkan disabilitas bahu pada kondisi frozen shoulder

\section{DAFTAR PUSTAKA}

1. Dharmawan, P. K., Tirtayasa, K., Wahyuddin., I. B., Sandi, I. N., Sugijanto. 2018. Kombinasi Caudal Traction dan Mobilization With Movement lebih baik daripada kombinasi Cauldal Traction dan Scapular Stability
Exercise dalam meningkatkan kemampuan fungsional pada External Shoulder Impigement Syndrome. Sport and Fitness Joulnal. Vol 6, No.2: 38-50.

2. Andrew, S. N., Jo, A. H. Adhesive Capsulitis. 2010. A Review of Current Treatment.The American Journal of Sports Medicine, Vol. 38,: No. 11: 2346

3. Boruah, L., Dutta, A., Deka, P., Roy, J. 2015. To Study The Effect of Scapular Mobilization Versus Mobilization with Movement to Reduce Pain and Improve Gleno-humeral Range of Motion in Adhesive Capsulitis of Shoulder: A Comparative Study. Int J Physiother. Vol 2 No.5, 811-818.

4. Chan, Y. B. H., Pua, Y. P., How, H. 2017. Physical Therapy in the Management of Frozen Shoulder. Singapore Med J, Vol 58, No12: 685-689

5. Martin, T. S., Kessler, M. 2016. Neurologic Interventions For Physical Therapy Third Edition. St. Louis: Elsevier Saunders.

6. Ritu, S., Anjali, K., Snehal, G. 2017. Added Effect of Muscle Energy Technique on Improving Functional Ability in Frozen Shoulder, Int. J. of Allied Med. Sci. and Clin. Research Vol5 No. 2 : 463-469.

7. Chaitow, L. 2006. Muscle Energy Techniques, Second Edition, Churchill Livingston, Edinburgh London New York Philadelphia Saint Lois Symdey Toronto.

8. Mawaddah., Bagiada, A. N., Sugijanto. 2015. Perbandingan Antara Kombinasi Latihan Stabilisasi Bahu Dan Traksi Humerus Ke Inferior Dengan Kombinasi Latihan Fungsional Bahu Dan Traksi Humerus Ke Inferior Dalam Menurunkan Disabilitas Bahu Dan Lengan Pada Subacromial Impigement Syndrome Mahasiswa Akademi Fisioterapi Widya Husada Semarang. Sport and Fitness Joulnal Volume 3, No.2 : 56-66.

9. Kumar, M., Logaban., Nathan, S., Rajalaxmi., Ramachandran, S. 2016. a comparative study on the effectivenes of muscle energy technique and mobilization coupld with ultrasound in 
patients with periarthritis of the shoulder joint. Int J Physiother. Vol 3, No. 5: 619624.

10. Sreenivasu, K., Paul, D. VK., Subramanian, MB., Sajeevan, T. Effectiveness of end range mobilization with scapular mobilization in frozen shoulder. IAIM. Vol. 3, No. 8: 53-58.

11. Narayan, Anupama, Jangga, Vinay. 2014. Efficacy of muscle energy technique on functional ability of shoulder in adhesive capsulitis. Journal of Exercise Science and Physiotherapy. Vol. 10, No. 2: 7276.

12. Fryer G. Muscle energy technique: An evidence-informed approach. Int $J$ Osteopath Med. Vol. 14, No.1:3-9.

13. ScibeK, J.S., Carcia, CR. Asessment of Scapulohumeral rhythm for scapular plane shoulder elevation using a modified digital inclinometer. Word $J$ Orthop 2012, Vol.3, No. 6 : 87-94.

14. Yamuna, Kumar, S., Krishna, R., Madhavi, K, 2018. Effectiveness of scapular and glenohumeral mobilization of rage of motion and disability of shoulder in subject with periarthritis of shoulder. Vol.2, No.8 : 813-816

15. Ravichandran, H., Balamurugan, J. 2015. Effect of proprioceptive neuromuscular facilitation stretch and muscle energy technique in the management of adhesive capsulitis of the shoulder. Saudi Journal of Sports Medicine. Vol. 15, No.2: 170175. 